\title{
Genetic relationships among the different phenotypes of Streptococcus dysgalactiae strains
}

\author{
Verônica V. Vieira, ${ }^{1}$ Lúcia M. Teixeira, ${ }^{1}$ Viviane Zahner, ${ }^{2}$ Hooman \\ Momen, ${ }^{2}$ Richard R. Facklam, ${ }^{3}$ Arnold G. Steigerwalt, ${ }^{3}$ Don J. Brenner ${ }^{3}$ \\ and Angela C. D. Castro'
}

Author for correspondence: Angela C. D. Castro. Tel: +55 212604193.
e-mail: immmade@microbio.ufrj.br

1 Instituto de Microbiologia,

The species Streptococcus dysgalactiae was proposed to accommodate a Universidade Federal do Rio de Janeiro, Rio de Janeiro 21941-590, Brazil heterogeneous group of streptococci associated with infections in animals and human beings. This taxon is now considered to include animal isolates of $\alpha$ haemolytic group C streptococci, previously called S. dysgalactiae; animal and human isolates of $\beta$-haemolytic group C streptococci, previously called ' $S$.

2 Instituto Oswaldo Cruz, Rio de Janeiro 21045, Brazil

3 Division of Bacterial and Mycotic Diseases, NCID, Centers for Disease Control and Prevention, Atlanta, GA 30333, USA equisimilis'; $\beta$-haemolytic group $L$ strains associated with infections in animals and, rarely, in humans; and $\beta$-haemolytic group $G$ strains isolated from humans. DNA-DNA reassociation experiments (hydroxyapatite method) and multilocus enzyme electrophoresis (MEE) were performed on reference strains and clinical isolates to determine the genetic relationships among these different phenotypic categories. DNA-DNA hybridization tests showed that they were related at the species level, despite the phenotypic and host heterogeneity. Both genotypic and phenotypic characterization indicated that S. dysgalactiae could be separated into two major sub-groups. The first subgroup contained $\alpha$-haemolytic strains that showed levels of DNA relatedness with the type strain of $S$. dysgalactiae ranging from 84 to $90 \%$ and from 82 to $88 \%$ under optimal $\left(55^{\circ} \mathrm{C}\right)$ and stringent $\left(70^{\circ} \mathrm{C}\right)$ conditions, respectively. The second sub-group contained $\beta$-haemolytic strains showing levels of relatedness ranging from 71 to $79 \%\left(55{ }^{\circ} \mathrm{C}\right)$ and from 62 to $73 \%\left(70^{\circ} \mathrm{C}\right)$. Percentage divergence varied from 0.5 to $1.0 \%$ ( $\alpha$-haemolytic group) and from 2.0 to $3.5 \%$ ( $\beta$-haemolytic group). A dendrogram based on phenotypic similarity between the enzyme bands produced by MEE showed a Jaccard similarity coefficient of 0.45 between the subclusters formed by the two sub-groups. The results of phenotypic and genotypic characterization were consistent with a published proposal to divide $S$. dysgalactiae into two subspecies, $S$. dysgalactiae subsp. dysgalactiae and S. dysgalactiae subsp. equisimilis, with a few modifications.

Keywords: Streptococcus dysgalactiae, multilocus enzyme electrophoresis, DNA-DNA hybridization, genetic relationships

\section{INTRODUCTION}

The classic Lancefield serological grouping has been of major importance in the classification and identification of $\beta$-haemolytic streptococci (Lancefield,
Abbreviations: $\mathrm{ET}$, electrophoretic type; MEE, multilocus enzyme electrophoresis; UPGMA, unweighted pair group method with arithmetic averages.
1933; Lancefield \& Hare, 1935). However, in most cases, when DNA-DNA relatedness studies were applied to the $\beta$-haemolytic streptococci, no correlation between genetic relationships and streptococcal group antigens was observed (Kilpper-Bälz \& Schleifer, 1984).

Streptococci belonging to Lancefield groups $\mathrm{C}$ and $\mathrm{G}$ are phenotypically and genotypically diverse. These streptococci can be initially characterized as forming either large or small colonies, which have been differen- 
V. V. Vieira and others

Table 1. Strains used in this study and their sources

\begin{tabular}{|c|c|c|c|c|c|}
\hline Name & Number* & $\begin{array}{c}\text { Other } \\
\text { designation(s) }\end{array}$ & $\begin{array}{l}\text { Received } \\
\text { from } \dagger\end{array}$ & Source & ET \\
\hline S. pyogenes & SS 745 & ATCC $12344^{\mathrm{T}}$ & ATCC & Human/group A & 1 \\
\hline S. pyogenes & SS1391 & A6883 & Lämmler & Orangutan/group A & 1 \\
\hline S. pyogenes & $145-93$ & & CCHSL-UFRJ & Human/group A & 2 \\
\hline S. canis & SS1353 & ATCC $43396^{\mathrm{T}}$ & Devriese & Bovine/group G & 3 \\
\hline S. canis & CA 146 & & CCHSL-UFRJ & Canine/group G & 4 \\
\hline S. canis & CA 086 & & CCHSL-UFRJ & Canine/group G & 4 \\
\hline S. canis & CA180 & & CCHSL-UFRJ & Canine/group G & 5 \\
\hline S. canis & SS1389 & G2643 & Lämmler & Canine/group $\mathrm{G}$ & 5 \\
\hline S. canis & SS1390 & G3232 & Lämmler & Canine/group G & 5 \\
\hline S. dysgalactiae & SS1346 & ATCC $43078^{\mathrm{T}}$ & ATCC & Bovine/ $\alpha$-haemol. group C & 6 \\
\hline S. dysgalactiae & P10 & & PESAGRO & Bovine $/ \alpha$-haemol. group C & 7 \\
\hline S. dysgalactiae & P16 & & PESAGRO & Bovine/ $\alpha$-haemol. group C & 7 \\
\hline S. dysgalactiae & P66 & & PESAGRO & Bovine $/ \alpha$-haemol. group C & 7 \\
\hline S. dysgalactiae & P74 & & PESAGRO & Bovine/ $\alpha$-haemol. group C & 7 \\
\hline S. dysgalactiae & P77 & & PESAGRO & Bovine $/ \boldsymbol{\alpha}$-haemol. group C & 7 \\
\hline S. dysgalactiae & P48 & & PESAGRO & Bovine/ $\alpha$-haemol. group C & 8 \\
\hline S. dysgalactiae & P41 & & PESAGRO & Bovine $/ \alpha$-haemol. group C & 9 \\
\hline S. dysgalactiae & P53 & & PESAGRO & Bovine $/ \alpha$-haemol. group C & 9 \\
\hline S. dysgalactiae & $\mathrm{P} 70$ & & PESAGRO & Bovine/ $\alpha$-haemol. group C & 9 \\
\hline S. dysgalactiae & P87 & & PESAGRO & Bovine/ $\alpha$-haemol. group C & 9 \\
\hline S. dysgalactiae & P141 & & PESAGRO & Bovine/ $\alpha$-haemol. group C & 10 \\
\hline Streptococcus sp. & SS18 & ATCC 9933 & ATCC & Canine/group L & 11 \\
\hline Streptococcus sp. & $1929-80$ & & $\mathrm{CDC}$ & Human vagina/group L & 11 \\
\hline Streptococcus sp. & SS87 & ATCC 9932 & ATCC & Canine/group L & 12 \\
\hline Streptococcus sp. & $2764-90$ & & $\mathrm{CDC}$ & Human/group L & 12 \\
\hline Streptococcus sp. & SS1383 & $\mathrm{L} 57 / 6$ & Lämmler & Bovine/group L & 12 \\
\hline Streptococcus sp. & SS1384 & T33 & Lämmler & Bovine/group L & 12 \\
\hline Streptococcus sp. & SS1385 & $\mathrm{T} 74$ & Lämmler & Bovine/group L & 12 \\
\hline Streptococcus sp. & SS1386 & P473 & Lämmler & Porcine/group L & 12 \\
\hline Streptococcus sp. & SS1387 & 957 & Lämmler & Porcine/group L & 12 \\
\hline Streptococcus sp. & SS1388 & 1110 & Lämmler & Porcine/group L & 12 \\
\hline 'S. equisimilis' & $609-96$ & & $\mathrm{CDC}$ & Frog/group C & 13 \\
\hline 'S. equisimilis' & $610-96$ & & $\mathrm{CDC}$ & Frog/group C & 13 \\
\hline Streptococcus sp. & SS 1380 & L21454 & Lämmler & Bovine/group L & 14 \\
\hline Streptococcus sp. & SS1381 & L519 & Lämmler & Porcine/group L & 15 \\
\hline Streptococcus sp. & SS1382 & $\mathrm{L} 50 / 15$ & Lämmler & Porcine/group L & 16 \\
\hline Streptococcus sp. & $1375-78$ & & $\mathrm{CDC}$ & Food/group L & 17 \\
\hline Streptococcus sp. & $1376-78$ & & $\mathrm{CDC}$ & Food/group L & 18 \\
\hline Streptococcus sp. & $1609-91$ & & $\mathrm{CDC}$ & Human blood/group L & 19 \\
\hline 'S. equisimilis' & 89043 & & CCHSL-UFRJ & Human/group C & 20 \\
\hline 'S. equisimilis' & 89093 & & CCHSL-UFRJ & Human/group C & 21 \\
\hline Streptococcus sp. & $024-91$ & & CCHSL-UFRJ & Human/group G & 22 \\
\hline Streptococcus sp. & $020-93$ & & CCHSL-UFRJ & Human/group G & 23 \\
\hline Streptococcus sp. & $009-91$ & & CCHSL-UFRJ & Human/group G & 24 \\
\hline Streptococcus sp. & $067-93$ & & CCHSL-UFRJ & Human/group G & 24 \\
\hline Streptococcus sp. & $011-91$ & & CCHSL-UFRJ & Human/group G & 24 \\
\hline 'S. equisimilis' & $022-93$ & & CCHSL-UFRJ & Human/group C & 25 \\
\hline 'S. equisimilis' & 89632 & & CCHSL-UFRJ & Human/group C & 25 \\
\hline 'S. equisimilis' & $218-84$ & & $\mathrm{CDC}$ & Human blood/group C & 25 \\
\hline 'S. equisimilis' & SS1069 & & $\mathrm{CDC}$ & Human throat/group C & 25 \\
\hline 'S. equisimilis' & 88212 & & CCHSL-UFRJ & Human/group C & 25 \\
\hline 'S. equisimilis' & 87194 & & CCHSL-UFRJ & Human/group C & 25 \\
\hline 'S. equisimilis' & $6560-91$ & & CCHSL-UFRJ & Human/group C & 26 \\
\hline 'S. equisimilis' & SS660 & ATCC 35666 & ATCC & Human vagina/group $\mathrm{C}$ & 26 \\
\hline
\end{tabular}


Table 1. (Cont.)

\begin{tabular}{|c|c|c|c|c|c|}
\hline Name & Number* & $\begin{array}{c}\text { Other } \\
\text { designation(s) }\end{array}$ & $\begin{array}{c}\text { Received } \\
\text { from } \dagger\end{array}$ & Source & ET \\
\hline 'S. equisimilis' & 90255 & & CCHSL-UFRJ & Human/group C & 27 \\
\hline 'S. equisimilis' & 88492 & & CCHSL-UFRJ & Human/group C & 28 \\
\hline 'S. equisimilis" & $2048-82$ & & $\mathrm{CDC}$ & Human/group C & 29 \\
\hline Streptococicus sp. & $006-91$ & & CCHSL-UFRJ & Human/group G & 29 \\
\hline 'S. equisimilis' & SS188 & & $\mathrm{CDC}$ & Human throat/group C & 30 \\
\hline "S. equisimilis" & 75302 & & CCHSL-UFRJ & Human/group C & 31 \\
\hline Streptococ'us sp. & 80455 & & CCHSL-UFRJ & Human/group G & 31 \\
\hline 'S. equisimilis' & $115-84$ & & $\mathrm{CDC}$ & Human blood/group C & 32 \\
\hline Streptococicus sp. & $184-93$ & & CCHSL-UFRJ & Human/group G & 33 \\
\hline 'S. equisimilis' & $001-94$ & & CCHSL-UFRJ & Human/group C & 33 \\
\hline 'S. equisimilis' & 88296 & & CCHSL-UFRJ & Human/group C & 34 \\
\hline Streptococicus sp. & $049-93$ & & CCHSL-UFRJ & Human/group G & 35 \\
\hline Streptocociss sp. & 81577 & & CCHSL-UFRJ & Human/group G & 36 \\
\hline 'S. equisimilis' & $3296-94$ & & $\mathrm{CDC}$ & Human/group C & 36 \\
\hline Streptococcus sp. & $007-91$ & & CCHSL-UFRJ & Human/group G & 37 \\
\hline Streptococcus sp. & $033-91$ & & CCHSL-UFRJ & Human/group G & 38 \\
\hline Streptococus sp. & $183-93$ & & CCHSL-UFRJ & Human/group G & 39 \\
\hline Streptococcus sp. & 85304 & & CCHSL-UFRJ & Human/group G & 39 \\
\hline Streptococcus sp. & $005-91$ & & CCHSL-UFRJ & Human/group G & 39 \\
\hline Streptococcus sp. & $030-91$ & & CCHSL-UFRJ & Human/group G & 40 \\
\hline Streptococ'us sp. & $034-91$ & & CCHSL-UFRJ & Human/group G & 41 \\
\hline Streptococicus sp. & $035-91$ & & CCHSL-UFRJ & Human/group G & 41 \\
\hline Streptococ'us sp. & $039-91$ & & CCHSL-UFRJ & Human/group G & 42 \\
\hline Streptococus sp. & $120-93$ & & CCHSL-UFRJ & Human/group G & 42 \\
\hline 'S. equisimilis' & CA125 & & CCHSL-UFRJ & Canine/group C & 43 \\
\hline 'S. equisimilis' & $1775-93$ & & $\mathrm{CDC}$ & Human/group C & 43 \\
\hline 'S. equisimilis' & $1778-93$ & & $\mathrm{CDC}$ & Human/group C & 44 \\
\hline 'S. equisimilis' & 91069 & & CCHSL-UFRJ & Human/group C & 45 \\
\hline 'S. equisimilis' & $1779-93$ & & $\mathrm{CDC}$ & Human/group C & 46 \\
\hline Streptococcus sp. & $044-91$ & & CCHSL-UFRJ & Human/group G & 47 \\
\hline 'S. equisimilis" & SS957 & & $\mathrm{CDC}$ & Human/group C & 48 \\
\hline Streptococ'us sp. & $025-91$ & & CCHSL-UFRJ & Human/group G & 49 \\
\hline Streptococcus sp. & $032-91$ & & CCHSL-UFRJ & Human/group G & 50 \\
\hline Streptococcus sp. & $026-91$ & & CCHSL-UFRJ & Human/group G & 50 \\
\hline Streptococius sp. & $037-91$ & & CCHSL-UFRJ & Human/group G & 50 \\
\hline 'S. equisimilis" & 91071 & & CCHSL-UFRJ & Human/group C & 50 \\
\hline Streptococus sp. & $105-93$ & & CCHSL-UFRJ & Human/group G & 51 \\
\hline Streptocoicus sp. & 78064 & & & Human/group G & 51 \\
\hline 'S. equisimilis' & $024-93$ & & CCHSL-UFRJ & Human/group C & 52 \\
\hline Streptococcus sp. & $019-91$ & & CCHSL-UFRJ & Human/group G & 53 \\
\hline Streptococius sp. & 81752 & & CCHSL-UFRJ & Human/group G & 54 \\
\hline Streptococ'us sp. & 81038 & & CCHSL-UFRJ & Human/group G & 55 \\
\hline 'S. equisimilis' & $040-93$ & & CCHSL-UFRJ & Human/group C & 56 \\
\hline 'S. equisimilis' & $3110-94$ & & $\mathrm{CDC}$ & Human blood/group C & 56 \\
\hline Streptococcus sp. & $042-91$ & & CCHSL-UFRJ & Human/group G & 57 \\
\hline 'S. equisimilis' & $2466-91$ & & CCHSL-UFRJ & Human/group C & 58 \\
\hline 'S. equisimilis' & 91082 & & CCHSL-UFRJ & Human abcess/group C & 59 \\
\hline Streptococus sp. & $003-91$ & & CCHSL-UFRJ & Human/group G & 60 \\
\hline Streptococcus sp. & $016-91$ & & CCHSL-UFRJ & Human/group G & 61 \\
\hline Streptococcus sp. & $010-91$ & & CCHSL-UFRJ & Human/group G & 61 \\
\hline Streptococus sp. & 89191 & & CCHSL-UFRJ & Human/group G & 62 \\
\hline Streptococus sp. & 81541 & & CCHSL-UFRJ & Human/group G & 63 \\
\hline Streptococius sp. & $015-91$ & & CCHSL-UFRJ & Human/group G & 63 \\
\hline Streptococcus sp. & $022-91$ & & CCHSL-UFRJ & Human/group G & 64 \\
\hline
\end{tabular}


Table 1. (Cont.)

\begin{tabular}{|c|c|c|c|c|c|}
\hline Name & Number* & $\begin{array}{c}\text { Other } \\
\text { designation(s) }\end{array}$ & $\begin{array}{c}\text { Received } \\
\text { from } \dagger\end{array}$ & Source & ET \\
\hline Streptococcus sp. & 81794 & & CCHSL-UFRJ & Human/group G & 65 \\
\hline S. equi subsp. equi & SS1344 & ATCC $33398^{\mathrm{T}}$ & ATCC & Horse & 66 \\
\hline S. equi subsp. zooepidemicus & SS1345 & ATCC $43079^{\mathrm{T}}$ & ATCC & Horse & 67 \\
\hline S. iniae & $2378-91$ & & $\mathrm{CDC}$ & Human blood & 68 \\
\hline S. iniae & SS1123 & ATCC 29177 & ATCC & Dolphin & 68 \\
\hline S. iniae & SS1056 & ATCC $29178^{\mathrm{T}}$ & ATCC & Dolphin & 69 \\
\hline S. iniae & SS1327 & & $\mathrm{CDC}$ & Tilapia & 69 \\
\hline S. iniae & SS1323 & & $\mathrm{CDC}$ & Tilapia & 69 \\
\hline S. iniae & SS1331 & & $\mathrm{CDC}$ & Tilapia & 69 \\
\hline S. iniae & SS1392 & $10 \mathrm{~A}$ & $\mathrm{CDC}$ & Tilapia & 69 \\
\hline S. iniae & SS1393 & $10 \mathrm{~J}$ & $\mathrm{CDC}$ & Tilapia & 69 \\
\hline$S$. iniae & SS1394 & $11 \mathrm{~F}$ & $\mathrm{CDC}$ & Sea bass & 69 \\
\hline S. agalactiae & SS617 & & $\mathrm{CDC}$ & Human & 70 \\
\hline
\end{tabular}

* SS, Standard strain from the Culture Collection of the Streptococcus Laboratory, Centers for Disease Control and Prevention, Atlanta, GA, USA.

+ ATCC, American Type Culture Collection, Rockville, MD, USA; CCHSL-UFRJ, Culture Collection of the $\beta$-Hemolytic Streptococci Laboratory, Federal University of Rio de Janeiro, Brazil; CDC, Centers for Disease Control and Prevention, Atlanta, GA, USA; PESAGRO, Pesquisas Agropecuárias do Rio de Janeiro, Brazil; Devriese, L. A. Devriese, University of Ghent, Belgium; Lämmler, Ch. Lämmler, Justus-Liebig Universität, Germany.

tiated on the basis of biochemical tests (Cimolai \& Mah, 1991; Lawrence et al., 1985) and DNA relatedness studies (Ezaki et al., 1986). The distinction between the colony forms is important because they have a different spectrum of clinical manifestations. The small-colony-forming strains belong to the 'Streptococcus milleri' group. Two major categories of the large-colony-forming Lancefield group C and G streptococci are considered to correspond to different species: the equine $\beta$-haemolytic Streptococcus equi (group C) with its subspecies equi and zooepidemicus (Farrow \& Collins, 1984), and Streptococcus canis (group G), carried by dogs and cats and an infrequent cause of mastitis in cattle (Devriese et al., 1986). Another species name, Streptococcus dysgalactiae, was revived by Garvie et al. (1983), but was considered to be restricted to $\alpha$-haemolytic group C strains of bovine origin. Subsequently, the DNA hybridization studies of Farrow \& Collins (1984) demonstrated that $S$. dysgalactiae exhibited high levels of DNA relatedness with large-colony-forming Lancefield group $\mathrm{C}$ (' $S$. equisimilis'), human group $\mathrm{G}$ and group $\mathrm{L} \beta$-haemolytic streptococci, suggesting that this group of organisms belong to a single species, $S$. dysgalactiae. These findings were confirmed by the studies of Kilpper-Bälz \& Schleifer (1984) and Ezaki et al. (1986). The species consists of distinct sub-groups based on serogroups, biotypes and hosts: (i) $S$. dysgalactiae, $\alpha$ haemolytic group $\mathrm{C}$ streptococci that can cause bovine mastitis; (ii) $\beta$-haemolytic group $\mathrm{C}$ strains named ' $S$. equisimilis' that can cause disease in animals; (iii) $\beta$ haemolytic group L strains that have been associated with infections in pigs, dogs, cattle and other animals, but rarely in humans; (iv) $\beta$-haemolytic group $\mathrm{C}$ strains, also named ' $S$. equisimilis', isolated from humans; and (v) $\beta$-haemolytic group $\mathrm{G}$ strains isolated from humans. Both group $\mathrm{C}$ and $\mathrm{G}$ streptococci have been recovered from humans as commensals as well as pathogens (Beebe \& Koneman, 1995; Cimolai et al., 1991; Lancefield \& Hare, 1935).

The phenotypic diversity found among components of this species has prompted investigations about the relationships among the sub-groups and possible division of the proposed species $S$. dysgalactiae. Efstratiou et al. (1994) observed biochemical differences among some sub-groups of this species. Vandamme et al. (1996) showed that these bacteria could be allocated into subspecies based on their physiological and biochemical properties and by numerical analysis of whole-cell protein profiles. The name $S$. dysgalactiae subsp. equisimilis was proposed for human strains belonging to groups $C$ and $G$, and strains of animal origin were placed in a distinct subspecies for which the name S. dysgalactiae subsp. dysgalactiae was proposed (Vandamme et al., 1996).

Methods for measuring genetic relatedness of these organisms have been employed in only a few of these studies. The purpose of the present study was to determine genetic relationships among strains belonging to Lancefield groups $\mathrm{C}, \mathrm{G}$ and $\mathrm{L}$, with emphasis on those resembling $S$. dysgalactiae, by using multilocus enzyme electrophoresis (MEE) and DNA hybridization. 


\section{METHODS}

Bacterial strains. The 121 streptococcal strains used in the study and their sources are listed in Table 1.

Phenotypic characterization of strains. The strains were characterized on the basis of serological grouping performed by the Lancefield hot-acid extraction procedure and precipitin reactions with specific antisera for group A, B, C, G and $\mathrm{L}$ streptococci prepared at the Centers for Disease Control and Prevention, Atlanta, GA, USA, or at the Institute of Microbiology, Federal University of Rio de Janeiro, Brazil. Phenotypic characteristics were tested by conventional biochemical tests as described previously (Facklam \& Washington, 1991). Strains were additionally tested using API 20 STREP (bioMérieux) according to the manufacturer's instructions. They were also tested for $\beta$-Dglucuronidase, $\beta$-D-galactosidase and $\alpha$-D-galactosidase activities, by using 4-methylumbelliferyl-conjugated substrates as described by Slifkin \& Gil (1983) and Whiley et al. (1990). Hyaluronidase and lysis of human fibrin were determined according to the method previously described (Vieira \& Castro, 1994).

Preparation of bacterial extracts for MEE. Each strain was grown in $100 \mathrm{ml}$ Todd-Hewitt broth (THB) at $37^{\circ} \mathrm{C}$ and harvested by centrifugation at $1000 \mathrm{~g}$ for $12 \mathrm{~min}$ at $4{ }^{\circ} \mathrm{C}$. The cells were suspended in $200 \mu \mathrm{l}$ lysis buffer containing $1 \%$ $(\mathrm{v} / \mathrm{v})$ Triton $\mathrm{X}-100,40 \mathrm{mM}$ potassium phosphate buffer (pH 7.5), $1 \mathrm{mM}$ EDTA and $1 \mathrm{mM}$ DTT. To each sample was

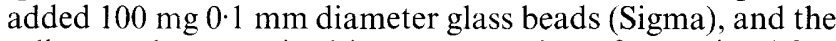
cells were homogenized in a vortex stirrer for $3 \mathrm{~min}$. After centrifugation at $12000 \mathrm{~g}$ for $30 \mathrm{~s}$, the supernatant (lysate) was stored at $-20^{\circ} \mathrm{C}$ until being tested by MEE.

MEE. The bacterial lysates were subjected to electrophoresis on $1 \%$ agarose horizontal gels according to procedures previously described (Momen \& Salles, 1985). Optimal electrophoretic conditions for each enzyme were determined by testing various buffer systems and variables as recommended by Selander et al. (1986). Thirty-three enzymic loci were screened for activity, but only the following 10 gave a consistent banding patterns for all strains and were used thereafter: nucleoside phosphorylase, EC 2.4.2.1 (NP); leucylalanine peptidase, EC 3.4.11.1 (PEP2); NAD-dependent glyceraldehyde-3-phosphate dehydrogenase, EC 1.2.1.12 (GAPD1); NADP-dependent glyceraldehyde-3phosphate dehydrogenase, EC 1.2.1.13 (GAPD2); leucine aminopeptidase, EC 3.4.11.1 (LAP); $\beta$-D-glucuronidase, EC 3.2.1.31 ( $\beta$-GUS); mannose-6-phosphate isomerase, EC 5.3.1.8 (MPI); leucylproline peptidase, EC 3.4.13.9 (PEPD); phosphoglucose isomerase, EC 5.3.1.9 (GPI); NAD-glycohydrolase, EC 3.2.2.6 (NADG). The electrophoresis buffer for the enzymes NP, PEP2, GAPD1, MPI, PEPD and GPI was Tris/citrate ( $\mathrm{pH} \mathrm{8.0)}$. A sodium phosphate buffer $(\mathrm{pH} \mathrm{8.0)}$ was used for electrophoresis of NADG, and Tris/citrate buffer $(\mathrm{pH} \mathrm{6.3)}$ was used for GAPD2, LAP and $\beta$-GUS. The staining methods used for NP, PEP2, PEPD and GPI were as described by Zahner et al. (1989). The enzyme MPI was stained according to the method of Cupolillo et al. (1994) and NADG as described by Harris \& Hopkinson (1976). For GAPD1, GAPD2 and $\beta$ GUS the staining procedures were performed as recommended by Pasteur et al. (1988) and for LAP as described by Selander et al. (1986). The distinctive electromorphs (mobility variants) of each enzyme were numbered in order of decreasing rate of anodal migration and were equated with alleles at corresponding structural gene loci. Strains that shared identical allelic profiles at all enzyme loci examined were recorded as belonging to the same electrophoretic type (ET).

Analysis of MEE data. The numerical analysis was performed using the NTSYS-pc software package (F. James Rohlf, version 1.7, Exeter Software). The Jaccard $\left(S_{\mathrm{J}}\right)$ and the simple-matching-type $\left(S_{\mathrm{SM}}\right)$ similarity coefficients (Sneath \& Sokal, 1973) were used to determine the relationships between the ETs. For this analysis, a matrix with presence/ absence of bands was built. The similarity matrix was transformed into a dendrogram by the unweighted pair group method with arithmetic averages (UPGMA). Cophenetic correlation coefficients (CCCs) were determined (Sneath \& Sokal, 1973) to assess the agreement between similarity values implied by the phenogram and those of the original similarity matrix. To estimate the genetic distance among species or groups of $\beta$-haemolytic streptococci a matrix of allele frequencies (electromorphs) was constructed and the Nei genetic distance between each pair of species was calculated. A phenogram was created from the matrix of Nei distances by the UPGMA clustering algorithm (Sneath \& Sokal, 1973).

DNA-DNA reassociation experiments. DNA-DNA reassociation studies were performed with selected strains. The strains were grown in $21 \mathrm{THB}$ at $37^{\circ} \mathrm{C}$ for $24 \mathrm{~h}$ with gentle shaking. Harvesting and lysis of the bacterial cells were performed as described by Teixeira et al. (1994), except that $500 \mu \mathrm{l}$ mutanolysin $\left(2000 \mathrm{U} \mathrm{ml}^{-1}\right)$ was also added to weaken the cell walls and the cells were incubated for $2.5 \mathrm{~h}$ instead of $30 \mathrm{~min}$. The procedures used to purify DNA and to determine DNA relatedness by the hydroxyapatite method have been described previously (Brenner et al., 1982). DNA was labelled enzymically in vitro with $\left[{ }^{32} \mathrm{P}\right] \mathrm{dCTP}$ by using a nick translation reagent kit (Gibco-BRL) as directed by the manufacturer. DNA hybridization experiments were performed at $55^{\circ} \mathrm{C}$ for optimal DNA reassociation and at $70^{\circ} \mathrm{C}$ for stringent conditions. Levels of divergence within related sequences were determined by assuming that each degree of heteroduplex instability, compared with the melting temperature of the homologous duplex, was caused by approximately $1 \%$ of unpaired bases. Percentage divergence was calculated to the nearest $0 \cdot 5 \%$.

\section{RESULTS}

All strains of $S$. dysgalactiae sub-groups were positive for acid production from ribose, starch and trehalose and produced alkaline phosphatase, arginine dehydrolase, leucine arylamidase and $\beta$-D-glucuronidase. Most of the strains produced hyaluronidase. Strains of all $S$. dysgalactiae sub-groups were negative for acetoin (Voges-Proskauer) production, and also for acid production from arabinose, inulin and raffinose. Most strains failed to produce pyrrolidonylarylamidase. Fifty-one per cent of the strains were positive for acid production from lactose.

Variable results were obtained for some characteristics when different methods were compared. According to the results of conventional tests, $47 \%$ of the strains gave positive reactions for aesculin hydrolysis, whilst only $30 \%$ of the strains were positive when the API 20 STREP was used. Similar findings were observed with $\beta$-D-galactosidase production. All strains were negative for $\beta$-D-galactosidase activity, as determined by API 20 STREP, although most of the $\beta$-haemolytic $S$. dysga- 
V. V. Vieira and others

Table 2. Phenotypic characteristics useful for the differentiation of $S$. dysgalactiae strains

\begin{tabular}{|c|c|c|c|c|c|c|c|c|c|}
\hline \multirow[t]{2}{*}{ Sub-group } & \multirow{2}{*}{$\begin{array}{l}\text { No. of } \\
\text { strains }\end{array}$} & \multicolumn{8}{|c|}{ Phenotypic characteristic* } \\
\hline & & НАЕМ & SOR & GLY & $\begin{array}{l}\beta \text {-D- } \\
\text { GAL }\end{array}$ & HIP & PAHF & BAC & GLU \\
\hline $\begin{array}{l}\text { S. dysgalactiae subsp. } \\
\text { dysgalactiae }\end{array}$ & 12 & $\alpha$ & $(+)$ & - & - & - & - & $\mathrm{S}$ & - \\
\hline \multicolumn{10}{|l|}{$\begin{array}{l}\text { S. dysgalactiae subsp. } \\
\text { equisimilis }\end{array}$} \\
\hline Human group $\mathrm{C}$ & 30 & $\beta$ & - & - & + & - & + & $\mathrm{R}$ & + \\
\hline Animal group $\mathrm{C}$ & 3 & $\beta$ & - & + & + & - & - & $\mathrm{R}$ & + \\
\hline Human group $\mathrm{G}$ & 39 & $\beta$ & - & - & + & - & + & $\mathrm{R}$ & + \\
\hline Group L & 16 & $\beta$ & - & + & + & $(+)$ & - & $\mathrm{S}$ & + \\
\hline
\end{tabular}

*HAEM, haemolysis; SOR, acid from sorbitol; GLY, acid from glycogen; $\beta$-D-GAL, $\beta$-Dgalactosidase; HIP, hydrolysis of hippurate; PAHF, proteolytic activity on human fibrin; BAC, bacitracin; $\alpha$-L-GLU, $\alpha$-L-glutamate aminopeptidase;,$+ 95 \%$ or more of strains positive; $(+)$, $70-80 \%$ of strains positive;,$- 95 \%$ or more of strains negative; S, susceptible; R, resistant.

lactiae sub-groups were positive when determined by using 4-methylumbelliferyl-conjugated $\beta$-D-galactoside as substrate. The differential phenotypic characteristics of $S$. dysgalactiae sub-groups are listed in Table 2.

All 10 enzymes assayed were polymorphic among the 121 streptococci strains tested. The mean number of alleles per locus was $5 \cdot 2$. Seventy ETs were identified. The electromorphic profiles of the ETs and the distribution of the strains into ETs are given in Table 3.

The relationships of the ETs are shown in the phenogram obtained using $S_{\mathrm{J}} /$ UPGMA (Fig. 1). The clusters obtained by $S_{\mathrm{SM}} /$ UPGMA (data not shown) corresponded to the clusters found by $S_{\mathrm{J}} /$ UPGMA. The $S_{\mathrm{J}}$ /UPGMA phenogram had high cophenetic correlation $(r=0.90)$. In this phenogram the ETs fell into six major clusters (marked I-VI) at the $0 \cdot 25 S_{\mathrm{J}}$ level. The clusters corresponded to different Streptococcus species: S. pyogenes, S. canis, S. dysgalactiae, S. equi, $S$. iniae and $S$. agalactiae, respectively. Each cluster had distinctive ETs and there was no sharing of ETs among the species studied. If a similarity value of 0.45 is considered, the ETs within cluster III could be divided into three distinctive subclusters. Subcluster a (ET 6-10) contains the $\alpha$-haemolytic group C streptococci. Subcluster b (ET 11-16) contains most of the strains of group L streptococci and two animal strains (ET 13) of 'S. equisimilis'. This subcluster was characterized by all the strains having allele PEP2 1 . Subcluster c (ET 17-65) includes strains of groups C, $\mathrm{G}$ and $\mathrm{L}$ streptococci. Some group L streptococcal strains (ET 17-19) still remained linked to human groups $\mathrm{C}$ and $\mathrm{G}$ streptococci because of the close association of ETs. Five ETs (ET 29, 31, 33, 36 and 50) were common to group $\mathrm{G}$ streptococci and human group C streptococci ('S. equisimilis').
Fig. 2 shows the genetic distance values among streptococci. The species were clustered according to the results obtained when the strains were compared by phenetic analysis.

DNA hybridization studies performed by using labelled DNAs from the type strain of $S$. dysgalactiae, ATCC 43078, an $\alpha$-haemolytic group C strain or from ATCC 35666, a human $\beta$-haemolytic group C strain of 'S. equisimilis', revealed that all $S$. dysgalactiae strains tested were in a single DNA relatedness group (Table 4). Two sub-groups were evident. DNA relatedness sub-group 1 contained all group $\mathrm{C} \alpha$-haemolytic $S$. dysgalactiae strains tested. The human group $\mathrm{G}$ streptococci, 'S. equisimilis' and group L streptococci were in DNA relatedness sub-group 2. The levels of DNA relatedness among strains belonging to group 1 and the type strain ATCC 43078 at optimal reassociation conditions $\left(55^{\circ} \mathrm{C}\right)$ ranged from 84 to $90 \%$ with $0 \cdot 5-1 \cdot 0 \%$ divergence. They were $82-88 \%$ related under stringent DNA reassociation conditions $\left(70{ }^{\circ} \mathrm{C}\right)$. Relatedness of the type strain to strains of sub-group 2 was $71-79 \%$ with $2 \cdot 0-3 \cdot 5 \%$ divergence at $55^{\circ} \mathrm{C}$, and $62-73 \%$ at $70{ }^{\circ} \mathrm{C}$. Similar results were obtained in reciprocal experiments using labelled DNA from DNA sub-group 2 strain ATCC 35666. The sub-group 2 strains were $77-90 \%$ related with $0 \cdot 5-2 \cdot 0 \%$ divergence at $55^{\circ} \mathrm{C}$ and $71-87 \%$ related at $70{ }^{\circ} \mathrm{C}$. Relatedness of sub-group 1 strains to ATCC 35666 was $73-76 \%$ with $2 \cdot 5-3 \cdot 5 \%$ divergence at $55^{\circ} \mathrm{C}$, and $59-69 \%$ at $70{ }^{\circ} \mathrm{C}$.

\section{DISCUSSION}

The phenotypic sub-groups of $S$. dysgalactiae are of importance in human and veterinary medicine. Those from veterinary sources have been considered as a cause of animal infections. In recent years, there has been increasing recognition of the pathogenic potential 
Table 3. Allelic profiles at 10 enzyme loci for 70 ETs of streptococci

\begin{tabular}{|c|c|c|c|c|c|c|c|c|c|c|c|c|c|}
\hline \multirow[t]{2}{*}{ ET } & \multirow{2}{*}{$\begin{array}{c}\text { No. of } \\
\text { Strains }\end{array}$} & \multirow[t]{2}{*}{ Group } & \multirow[t]{2}{*}{ Species } & \multicolumn{10}{|c|}{ Allele at enzyme locus* } \\
\hline & & & & $\mathbf{N P}$ & PEP2 & GAPD1 & GAPD2 & LAP & $\beta$-GUS & MPI & PEPD & GPI & NADG \\
\hline 1 & 2 & $\mathrm{~A}$ & S. pyogenes & 3 & 1 & 5 & 3 & 5 & 0 & 1 & 5 & 4 & 6 \\
\hline 2 & 1 & A & S. pyogenes & 3 & 2 & 5 & 3 & 5 & 0 & 1 & 4 & 4 & 6 \\
\hline 3 & 1 & $\mathrm{G}$ & S. canis & 2 & 2 & 6 & 3 & 3 & 0 & 4 & 4 & 4 & 3 \\
\hline 4 & 2 & G & S. canis & 2 & 2 & 6 & 3 & 5 & 0 & 4 & 4 & 4 & 3 \\
\hline 5 & 3 & G & S. canis & 2 & 2 & 6 & 3 & 5 & 0 & 4 & 3 & 4 & 3 \\
\hline 6 & 1 & $\mathrm{C}$ & S. dysgalactiae & 2 & 2 & 3 & 3 & 5 & 5 & 6 & 6 & 4 & 5 \\
\hline 7 & 5 & $\mathrm{C}$ & S. dysgalactiae & 3 & 2 & 3 & 3 & 5 & 5 & 6 & 6 & 4 & 5 \\
\hline 8 & 1 & $\mathrm{C}$ & S. dysgalactiae & 3 & 2 & 3 & 3 & 5 & 4 & 6 & 6 & 4 & 5 \\
\hline 9 & 4 & $\mathrm{C}$ & S. dysgalactiae & 3 & 2 & 5 & 3 & 5 & 5 & 6 & 6 & 4 & 5 \\
\hline 10 & 1 & $\mathrm{C}$ & S. dysgalactiae & 3 & 2 & 5 & 3 & 5 & 4 & 6 & 6 & 4 & 5 \\
\hline 11 & 2 & $\mathrm{~L}$ & Streptococcus sp. & 3 & 1 & 4 & 3 & 3 & 4 & 5 & 6 & 4 & 7 \\
\hline 12 & 8 & $\mathrm{~L}$ & Streptococcus sp. & 3 & 1 & 4 & 3 & 3 & 4 & 6 & 6 & 4 & 7 \\
\hline 13 & 2 & $\mathrm{C}$ & 'S. equisimilis' & 3 & 1 & 4 & 3 & 4 & 4 & 6 & 6 & 4 & 7 \\
\hline 14 & 1 & $\mathrm{~L}$ & Streptococcus sp. & 3 & 1 & 3 & 3 & 3 & 4 & 6 & 6 & 4 & 7 \\
\hline 15 & 1 & $\mathrm{~L}$ & Streptococcus sp. & 3 & 1 & 3 & 3 & 3 & 3 & 6 & 6 & 4 & 7 \\
\hline 16 & 1 & $\mathrm{~L}$ & Streptococcus sp. & 3 & 1 & 4 & 3 & 3 & 3 & 6 & 6 & 4 & 7 \\
\hline 17 & 1 & $\mathrm{~L}$ & Streptococcus sp. & 2 & 2 & 4 & 3 & 3 & 4 & 5 & 6 & 4 & 7 \\
\hline 18 & 1 & $\mathrm{~L}$ & Streptococcus sp. & 2 & 2 & 4 & 3 & 3 & 4 & 6 & 6 & 4 & 7 \\
\hline 19 & 1 & $\mathrm{~L}$ & Streptococcus sp. & 2 & 2 & 4 & 3 & 4 & 4 & 6 & 6 & 4 & 7 \\
\hline 20 & 1 & $\mathrm{C}$ & 'S. equisimilis' & 2 & 2 & 2 & 3 & 3 & 3 & 6 & 6 & 4 & 7 \\
\hline 21 & 1 & $\mathrm{C}$ & 'S. equisimilis' & 2 & 2 & 2 & 3 & 3 & 4 & 6 & 6 & 4 & 7 \\
\hline 22 & 1 & G & Streptococcus sp. & 2 & 2 & 2 & 3 & 3 & 2 & 6 & 6 & 4 & 7 \\
\hline 23 & 1 & G & Streptococcus sp. & 2 & 2 & 1 & 3 & 3 & 3 & 6 & 6 & 4 & 7 \\
\hline 24 & 3 & G & Streptococcus sp. & 2 & 2 & 1 & 3 & 3 & 4 & 6 & 6 & 4 & 7 \\
\hline 25 & 6 & $\mathrm{C}$ & 'S. equisimilis' & 2 & 2 & 2 & 3 & 4 & 2 & 5 & 6 & 4 & 7 \\
\hline 26 & 2 & $\mathrm{C}$ & 'S. equisimilis' & 2 & 2 & 1 & 3 & 3 & 1 & 5 & 6 & 4 & 7 \\
\hline 27 & 1 & $\mathrm{C}$ & 'S. equisimilis' & 2 & 2 & 2 & 3 & 2 & 5 & 6 & 6 & 4 & 7 \\
\hline 28 & 1 & $\mathrm{C}$ & 'S. equisimilis' & 2 & 2 & 2 & 3 & 3 & 1 & 5 & 6 & 4 & 7 \\
\hline 29 & 2 & $\mathrm{C}, \mathrm{G}$ & Streptococcus sp. & 2 & 2 & 2 & 3 & 3 & 5 & 6 & 6 & 4 & 7 \\
\hline 30 & 1 & $\mathrm{C}$ & 'S. equisimilis' & 2 & 2 & 1 & 3 & 3 & 1 & 5 & 6 & 4 & 7 \\
\hline 31 & 2 & $\mathrm{C}, \mathrm{G}$ & Streptococcus sp. & 2 & 2 & 1 & 3 & 3 & 2 & 5 & 6 & 4 & 7 \\
\hline 32 & 1 & $\mathrm{C}$ & 'S. equisimilis' & 3 & 2 & 3 & 3 & 3 & 2 & 5 & 6 & 4 & 7 \\
\hline 33 & 2 & $\mathrm{C}, \mathrm{G}$ & Streptococcus sp. & 2 & 2 & 3 & 3 & 3 & 2 & 5 & 6 & 4 & 7 \\
\hline 34 & 1 & $\mathrm{C}$ & 'S. equisimilis' & 2 & 2 & 4 & 3 & 4 & 3 & 5 & 6 & 4 & 7 \\
\hline 35 & 1 & G & Streptococcus sp. & 2 & 2 & 4 & 3 & 3 & 3 & 5 & 6 & 4 & 7 \\
\hline 36 & 2 & $\mathrm{C}, \mathrm{G}$ & Streptococcus sp. & 2 & 2 & 2 & 3 & 3 & 3 & 5 & 6 & 4 & 7 \\
\hline 37 & 1 & G & Streptococcus sp. & 2 & 2 & 3 & 3 & 4 & 3 & 5 & 6 & 4 & 7 \\
\hline 38 & 1 & G & Streptococcus sp. & 2 & 1 & 2 & 3 & 3 & 3 & 5 & 6 & 4 & 8 \\
\hline 39 & 3 & G & Streptococcus sp. & 2 & 2 & 3 & 3 & 3 & 2 & 5 & 6 & 4 & 8 \\
\hline 40 & 1 & G & Streptococcus sp. & 2 & 2 & 3 & 3 & 3 & 0 & 5 & 6 & 4 & 8 \\
\hline 41 & 2 & $\mathrm{G}$ & Streptococcus sp. & 2 & 2 & 3 & 3 & 3 & 3 & 5 & 6 & 4 & 8 \\
\hline 42 & 2 & G & Streptococcus sp. & 2 & 2 & 3 & 3 & 3 & 4 & 5 & 6 & 4 & 8 \\
\hline 43 & 2 & $\mathrm{C}$ & 'S. equisimilis' & 3 & 2 & 4 & 3 & 3 & 4 & 5 & 6 & 4 & 7 \\
\hline 44 & 1 & $\mathrm{C}$ & 'S. equisimilis' & 3 & 2 & 4 & 3 & 2 & 4 & 5 & 6 & 4 & 7 \\
\hline 45 & 1 & $\mathrm{C}$ & 'S. equisimilis' & 2 & 2 & 4 & 3 & 2 & 4 & 5 & 6 & 4 & 7 \\
\hline 46 & 1 & $\mathrm{C}$ & 'S. equisimilis' & 2 & 2 & 2 & 3 & 2 & 4 & 5 & 6 & 4 & 7 \\
\hline 47 & 1 & $\mathrm{G}$ & Streptococcus sp. & 3 & 2 & 2 & 3 & 2 & 4 & 5 & 6 & 4 & 7 \\
\hline 48 & 1 & $\mathrm{C}$ & 'S. equisimilis' & 3 & 2 & 3 & 3 & 4 & 0 & 5 & 6 & 4 & 7 \\
\hline 49 & 1 & $\mathrm{G}$ & Streptococcus sp. & 3 & 2 & 3 & 3 & 4 & 4 & 5 & 6 & 4 & 7 \\
\hline 50 & 4 & $1 \mathrm{C}, 3 \mathrm{G}$ & Streptococcus sp. & 3 & 2 & 3 & 3 & 3 & 4 & 5 & 6 & 4 & 7 \\
\hline 51 & 2 & $\mathrm{G}$ & Streptococcus sp. & 3 & 2 & 3 & 3 & 2 & 4 & 5 & 6 & 4 & 7 \\
\hline 52 & 1 & G & Streptococcus sp. & 3 & 2 & 3 & 3 & 2 & 3 & 5 & 6 & 4 & 7 \\
\hline 53 & 1 & G & Streptococcus sp. & 3 & 2 & 3 & 3 & 3 & 3 & 5 & 6 & 4 & 7 \\
\hline
\end{tabular}


Table 3. (Cont.)

\begin{tabular}{|c|c|c|c|c|c|c|c|c|c|c|c|c|c|}
\hline \multirow[t]{2}{*}{ ET } & \multirow{2}{*}{$\begin{array}{l}\text { No. of } \\
\text { Strains }\end{array}$} & \multirow[t]{2}{*}{ Group } & \multirow[t]{2}{*}{ Species } & \multicolumn{10}{|c|}{ Allele at enzyme locus* } \\
\hline & & & & NP & PEP2 & GAPD1 & GAPD2 & LAP & $\beta$-GUS & MPI & PEPD & GPI & NADG \\
\hline 54 & 1 & $\mathrm{G}$ & Streptococcus $\mathrm{sp}$. & 3 & 2 & 3 & 3 & 3 & 3 & 5 & 6 & 4 & 8 \\
\hline 55 & 1 & G & Streptococcus sp. & 3 & 2 & 3 & 3 & 4 & 0 & 5 & 6 & 4 & 8 \\
\hline 56 & 2 & $\mathrm{C}$ & 'S. equisimilis' & 3 & 2 & 2 & 3 & 3 & 3 & 5 & 6 & 4 & 7 \\
\hline 57 & 1 & G & Streptococcus sp. & 3 & 2 & 2 & 3 & 3 & 0 & 5 & 6 & 4 & 7 \\
\hline 58 & 1 & $\mathrm{C}$ & 'S. equisimilis' & 3 & 2 & 2 & 3 & 3 & 4 & 5 & 6 & 4 & 7 \\
\hline 59 & 1 & $\mathrm{C}$ & 'S. equisimilis' & 3 & 2 & 2 & 3 & 3 & 2 & 5 & 6 & 4 & 7 \\
\hline 60 & 1 & G & Streptococcus sp. & 3 & 2 & 2 & 3 & 3 & 0 & 6 & 6 & 4 & 7 \\
\hline 61 & 2 & G & Streptococcus sp. & 3 & 2 & 2 & 3 & 3 & 4 & 6 & 6 & 4 & 7 \\
\hline 62 & 1 & $\mathrm{G}$ & Streptococcus sp. & 3 & 2 & 2 & 3 & 3 & 2 & 6 & 6 & 4 & 7 \\
\hline 63 & 2 & $\mathrm{G}$ & Streptococcus sp. & 3 & 2 & 2 & 3 & 3 & 3 & 6 & 6 & 4 & 7 \\
\hline 64 & 1 & $\mathrm{G}$ & Streptococcus sp. & 3 & 2 & 2 & 3 & 4 & 4 & 6 & 6 & 4 & 7 \\
\hline 65 & 1 & $\mathrm{G}$ & Streptococcus sp. & 3 & 2 & 2 & 3 & 4 & 3 & 6 & 6 & 4 & 7 \\
\hline 66 & 1 & $\mathrm{C}$ & S. equi subsp. equi & 2 & 1 & 6 & 1 & 1 & 1 & 7 & 3 & 2 & 2 \\
\hline 67 & 1 & $\mathrm{C}$ & $\begin{array}{l}\text { S. equi subsp. } \\
\text { zooepidemicus }\end{array}$ & 1 & 1 & 6 & 2 & 1 & 1 & 8 & 3 & 2 & 2 \\
\hline 68 & 2 & - & S. iniae & 3 & 1 & 5 & 2 & 2 & 1 & 3 & 1 & 1 & 4 \\
\hline 69 & 7 & - & S. iniae & 2 & 1 & 5 & 2 & 2 & 1 & 3 & 1 & 1 & 4 \\
\hline 70 & 1 & B & S. agalactiae & 1 & 3 & 6 & 4 & 0 & 1 & 2 & 2 & 3 & 1 \\
\hline
\end{tabular}

*NP, Nucleoside phosphorylase; PEP2, leucylalanine peptidase; GAPD1, NAD-dependent glyceraldehyde-3-phosphate dehydrogenase; GAPD2, NADP-dependent glyceraldehyde-3-phosphate dehydrogenase; LAP, leucine aminopeptidase; $\beta$-GUS, $\beta$-Dglucuronidase; MPI, mannose-6-phosphate isomerase; PEPD, leucylproline peptidase; GPI, phosphoglucose isomerase; NADG, NAD-glycohydrolase.

of group G streptococci and ' $S$. equisimilis', subgroups of $S$. dysgalactiae isolated from humans. These organisms have a similar clinical spectrum. They can cause a variety of illnesses, ranging from acute pharyngitis (Cimolai et al., 1991) to severe infections, such as septicaemia and endocarditis (Bucher \& Gaustad, 1990; Carmeli et al., 1995). Many of these infections have occurred in patients with some degree of immunosuppression. Recently, Beebe \& Koneman (1995) described a possible association of group $G$ with neoplastic disease. Consequently, the establishment of genetic relationships among $S$. dysgalactiae subgroups is necessary for answering certain basic questions concerning the epidemiology, pathogenicity and classification of these organisms.

MEE has been successfully applied to taxonomic studies of many organisms (Balmelli \& Piffaretti, 1996; Cupolillo et al., 1994; Musser et al., 1986). Although this method has not been used to classify strains to the subspecies level, MEE results were compatible with the results of DNA-DNA hybridization, a method considered the standard reference technique in bacterial species identification. Subspecific classification may also reflect differences in DNA relatedness, in addition to other criteria such as phenotypic characters, pathogenicity and host range (Wayne et al., 1987). We used MEE to determine the phenetic and genetic affinities among the sub-groups of $S$. dysgalactiae. In this study two different techniques were used in the analysis of the MEE data. The first analysis used a coefficient of similarity to determine the phenetic relationships between ETs (Fig. 1). In the second analysis, genotypes were inferred from electromorphs, and from these data a measure of genetic distance among the sub-groups was calculated (Fig. 2). Similar classifications were obtained using the two different analyses. The results showed that the species of pyogenic streptococci could be differentiated by this method. MEE data could also be used to distinguish between $\alpha$-haemolytic and $\beta$ haemolytic $S$. dysgalactiae strains. Our data confirm a previous report of Bert et al. (1995), which showed that MEE had potential for the differentiation of pyogenic streptococci. These authors did not report separation of the sub-groups of this species. We used different enzymic systems, buffer systems and gels than those used by Bert et al. (1995) to achieve differentiation of the subspecies of $S$. dysgalactiae.

DNA relatedness has been recommended as the method of choice for differentiating species (Stackebrandt \& Goebel, 1994; Wayne et al., 1987). The phylogenetic definition of a species is a group of 'strains with approximately $70 \%$ or greater DNA-DNA relatedness and with $5{ }^{\circ} \mathrm{C}$ or less $\Delta T_{\mathrm{m}}$ '. Both values must be considered (Wayne et al., 1987). It has also been demonstrated that the subspecies concept is phylogenetically valid, on the basis of the frequency of distribution of levels of divergence within related sequences and preferentially high-level of intraspecies 


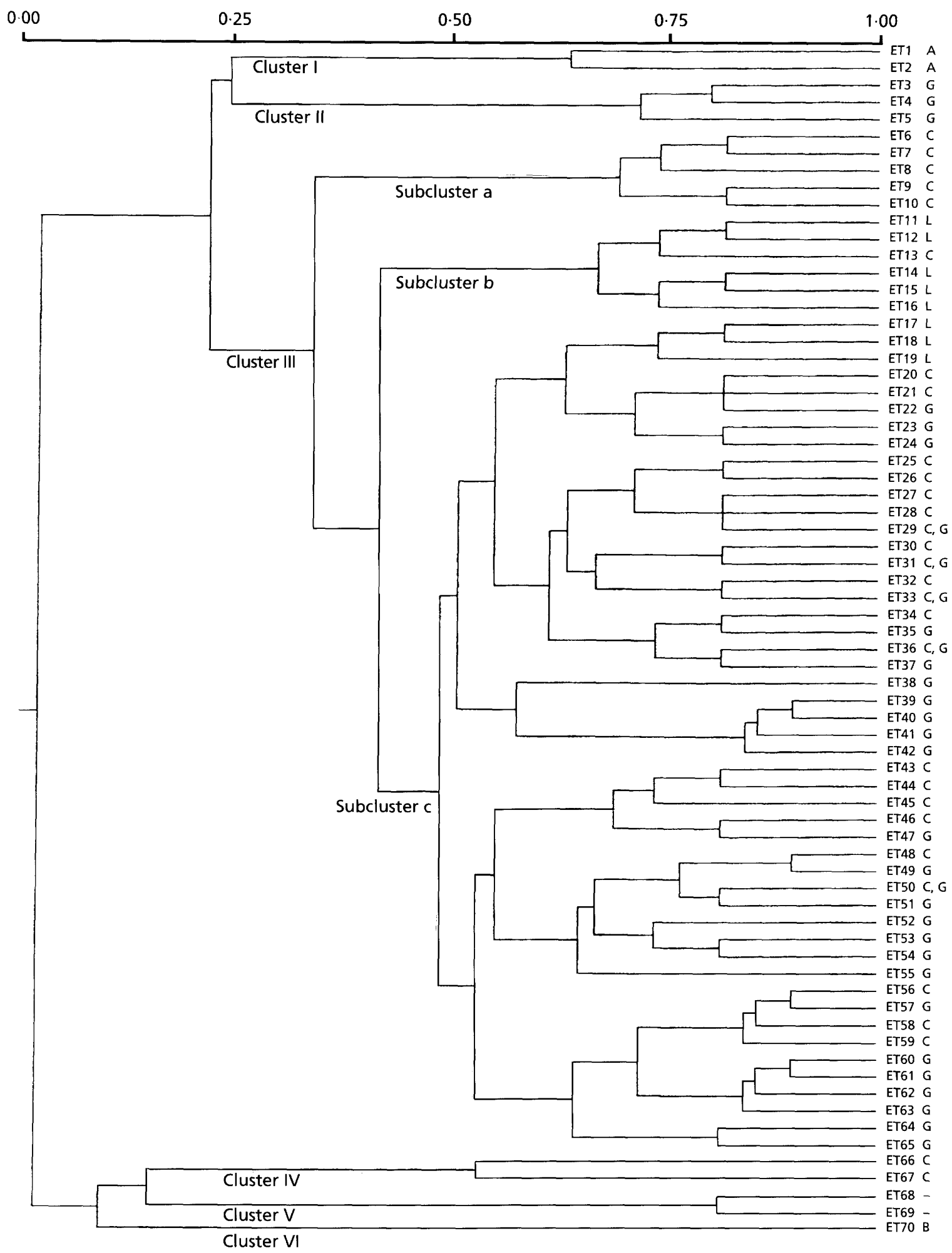

Fig. 1. Phenogram showing the Jaccard similarity coefficient between the ETs of streptococcal strains. Clusters I, II, III, IV, $\mathrm{V}$ and $\mathrm{VI}$ correspond to $\mathrm{S}$. pyogenes, S. canis, S. dysgalactiae, S. equi, S. iniae and S. agalactiae, respectively. Subcluster a contains $\alpha$-haemolytic $S$. dysgalactiae strains; subcluster b contains $\beta$-haemolytic group L streptococci and animal group $C$ ('S. equisimilis'), and subcluster c contains $\beta$-haemolytic groups $C, G$ and $L$ streptococci. 


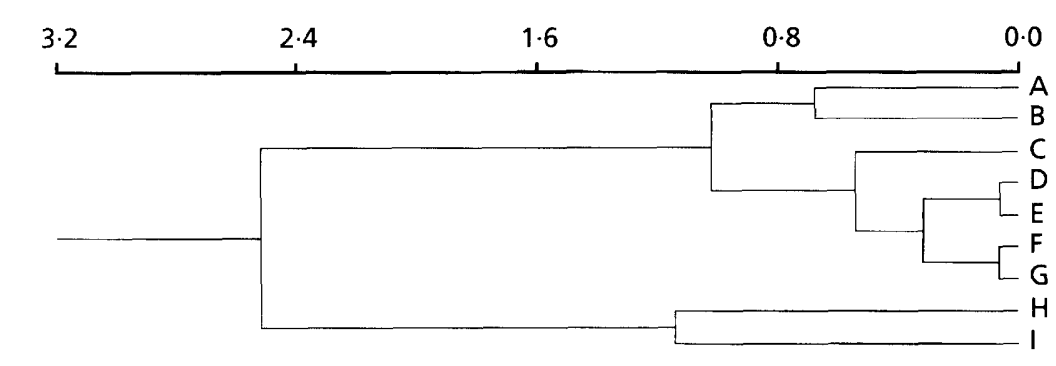

Fig. 2. Nei genetic distance between streptococcal species and sub-groups of S. dysgalactiae. A, S. pyogenes; B, S. canis; $C, \alpha$-haemolytic $S$. dysgalactiae strains; D, human $\beta$-haemolytic group C streptococci; $\mathrm{E}$, human $\beta$-haemolytic group $\mathrm{G}$ streptococci; $\mathrm{F}$, human $\beta$-haemolytic group $L$ streptococci; $\mathrm{G}$, animal $\beta$-haemolytic group $\mathrm{C}$ streptococci; H, S. equi; I, S. iniae.

Table 4. Levels of DNA relatedness of $S$. dysgalactiae and other Streptococcus species

All reactions were done in duplicate.

\begin{tabular}{|c|c|c|c|c|}
\hline \multirow[t]{3}{*}{ Source of unlabelled DNA } & \multicolumn{4}{|c|}{ Relative binding ( $\%$ ) with labelled DNA from: } \\
\hline & \multicolumn{2}{|c|}{ S. dysgalactiae ATCC $43078^{\mathrm{T}}$} & \multicolumn{2}{|c|}{ 'S. equisimilis' ATCC 35666} \\
\hline & $55^{\circ} \mathrm{C}\left(\% \mathrm{D}^{*}\right)$ & $7^{\circ} \mathrm{C}$ & $55^{\circ} \mathrm{C}\left(\% \mathrm{D}^{*}\right)$ & $70{ }^{\circ} \mathrm{C}$ \\
\hline S. dysgalactiae ATCC $43078^{\mathrm{T}}$ & $100(0 \cdot 0)$ & 100 & $75(2 \cdot 5)$ & 64 \\
\hline S. dysgalactiae $\mathrm{P} 41$ & $90(1 \cdot 0)$ & 88 & $73(3 \cdot 0)$ & 69 \\
\hline S. dysgalactiae $\mathrm{P} 48$ & $88(1 \cdot 0)$ & 86 & $76(3 \cdot 0)$ & 67 \\
\hline S. dysgalactiae P 70 & $89(1 \cdot 0)$ & 85 & $74(3 \cdot 5)$ & 59 \\
\hline S. dysgalactiae P 72 & $84(0 \cdot 5)$ & 87 & $74(3 \cdot 5)$ & 61 \\
\hline S. dysgalactiae P 74 & $90(0 \cdot 5)$ & 87 & $74(3 \cdot 5)$ & 69 \\
\hline S. dysgalactiae P 87 & $86(0 \cdot 5)$ & 82 & $76(3 \cdot 5)$ & 66 \\
\hline 'S. equisimilis' ATCC 35666 & $77(2 \cdot 5)$ & 68 & $100(0 \cdot 0)$ & 100 \\
\hline 'S. equisimilis' SS1069 & $77(2 \cdot 5)$ & 69 & $88(1 \cdot 0)$ & 81 \\
\hline 'S. equisimilis' SS188 & $75(2 \cdot 5)$ & 69 & $88(0 \cdot 5)$ & 86 \\
\hline 'S. equisimilis' 2466-91 & $71(2 \cdot 5)$ & 65 & $83(1 \cdot 0)$ & 81 \\
\hline 'S. equisimilis' 88296 & $71(2 \cdot 5)$ & 64 & $84(1 \cdot 0)$ & 87 \\
\hline 'S. equisimilis' CDC 115-84 & $76(3.0)$ & 65 & $83(1 \cdot 0)$ & 83 \\
\hline 'S. equisimilis' CDC 3296-94 & $71(2 \cdot 5)$ & 62 & $89(0 \cdot 5)$ & 85 \\
\hline 'S. equisimilis' 25 & $76(3 \cdot 0)$ & 72 & $83(1.0)$ & 80 \\
\hline 'S. equisimilis' CDC 609-96 & $77(2 \cdot 5)$ & 73 & $83(1 \cdot 0)$ & 82 \\
\hline 'S. equisimilis' CDC 610-96 & $76(2 \cdot 5)$ & 71 & $84(1 \cdot 0)$ & 81 \\
\hline Group G Streptococcus ATCC 12394 & $79(3 \cdot 0)$ & 72 & $85(1 \cdot 0)$ & 80 \\
\hline Group G Streptococcus 049-93 & $76(3 \cdot 5)$ & 68 & $84(1 \cdot 0)$ & 81 \\
\hline Group G Streptococcus $120-93$ & $77(3 \cdot 0)$ & 69 & $92(1 \cdot 0)$ & 84 \\
\hline Group G Streptococcus 006-91 & $75(3 \cdot 5)$ & 69 & $88(1 \cdot 0)$ & 85 \\
\hline Group G Streptococcus $032-91$ & $76(3.0)$ & 67 & $88(1 \cdot 5)$ & 82 \\
\hline Group G Streptococcus $042-91$ & $77(3 \cdot 0)$ & 71 & $89(1 \cdot 5)$ & 84 \\
\hline Group L Streptococcus ATCC 9933 & $77(2 \cdot 0)$ & 68 & $78(2 \cdot 0)$ & 71 \\
\hline Group L Streptococcus ATCC 9932 & $79(2 \cdot 0)$ & 70 & $81(2 \cdot 0)$ & 74 \\
\hline Group L Streptococcus CDC 1375-91 & $72(2 \cdot 0)$ & 68 & $76(1 \cdot 5)$ & 73 \\
\hline Group L Streptococcus CDC 1376-91 & $74(2 \cdot 0)$ & 69 & $77(2 \cdot 0)$ & 73 \\
\hline Group L Streptococcus CDC 1929-80 & $78(2 \cdot 0)$ & 70 & $77(1 \cdot 5)$ & 75 \\
\hline Group L Streptococcus CDC 2764-90 & $77(3 \cdot 0)$ & 69 & $77(1 \cdot 5)$ & 75 \\
\hline Group L Streptococcus CDC 1609-91 & $72(2 \cdot 0)$ & 66 & $81(1 \cdot 0)$ & 80 \\
\hline S. canis ATCC $43396^{\mathrm{T}}$ & 49 (ND) & ND & $46(\mathrm{ND})$ & ND \\
\hline S. canis CA 146 & $48(\mathrm{ND})$ & ND & $46(\mathrm{ND})$ & ND \\
\hline S. canis CA 180 & $47(\mathrm{ND})$ & ND & $44(\mathrm{ND})$ & ND \\
\hline S. equi subsp. equi ATCC $33398^{\mathrm{T}}$ & $22(\mathrm{ND})$ & ND & $18(\mathrm{ND})$ & ND \\
\hline S. equi subsp. zooepidemicus ATCC $43079^{\mathrm{T}}$ & $25(\mathrm{ND})$ & ND & $21(\mathrm{ND})$ & ND \\
\hline S. pyogenes ATCC $12344^{\mathrm{T}}$ & $47(\mathrm{ND})$ & ND & $48(\mathrm{ND})$ & ND \\
\hline S. iniae CDC 2378-91 & $25(\mathrm{ND})$ & ND & $23(\mathrm{ND})$ & ND \\
\hline
\end{tabular}

ND, Not determined.

* \% D, percentage divergence. 
relatedness (Wayne et al., 1987). Studies by Farrow \& Collins (1984) and Kilpper-Bälz \& Schleifer (1984), showed that the sub-groups of $S$. dysgalactiae belong to a single species on the basis of only high-level DNA relatedness to the type strain ATCC 43078. These hybridization studies were performed by the membrane filter method, and levels of divergence and DNA reassociation at a stringent temperature $\left(70^{\circ} \mathrm{C}\right)$ were not determined.

The results of our DNA-DNA reassociation experiments have shown that strains of all of the phenotypic sub-groups were genetically related at the species level. Two DNA relatedness sub-groups were present when the percentage of divergence within related sequences was considered. DNA relatedness sub-group 1 contained $\alpha$-haemolytic strains, and sub-group 2 contained the $\beta$-haemolytic strains. The results obtained by MEE correlated with results obtained by DNA-DNA hybridization. The $\alpha$-haemolytic group C strains that were clustered independently by MEE clustered in DNA relatedness sub-group 1. According to MEE data and DNA-DNA hybridization studies, $\beta$-haemolytic group L and group C ('S. equisimilis') streptococi from animals were closely related to human $\beta$-haemolytic groups $\mathrm{C}$ and $\mathrm{G}$ strains. For strains of $\beta$-haemolytic group L streptococci, the levels of divergence in related sequences were slightly lower than observed in the other strains of this group. This sub-group belonged to cluster III as determined by MEE, and most of these strains were placed into a single subcluster (b). However, some of these strains remained in another subcluster (c) with human $\beta$ haemolytic group $\mathrm{C}$ and group $\mathrm{G}$ streptococci.

The sub-groups of $S$. dysgalactiae could also be differentiated on the basis of phenotypic characteristics. The $\alpha$-haemolytic group $\mathrm{C}$ strains were distinguished from human $\beta$-haemolytic ' $S$. equisimilis' and also group $\mathrm{G}$ because they failed to produce $\alpha-\mathrm{L}$ glutamate aminopeptidase, $\beta$-D-galactosidase and proteolytic activity on human fibrin. They were susceptible to bacitracin and most of them produced acid from sorbitol. Strains belonging to this sub-group differed from $\beta$-haemolytic group L strains on the basis of their inability to produce $\alpha$-L-glutamate aminopeptidase and $\beta$-D-galactosidase, and most strains fermented sorbitol. Human strains of $\beta$-haemolytic group $\mathrm{C}$ and $\mathrm{G}$ could be distinguished only on the basis of serological characteristics. These strains differed from group L strains in their ability to produce fibrinolysin, in their inability to produce acid from glycogen and in their resistance to bacitracin. In addition, some of the L strains hydrolysed hippurate. The ' $S$. equisimilis' strains associated with animals could be distinguished from human ' $S$. equisimilis' strains by glycogen fermentation and by failure to produce fibrinolysin. Overall, the results of biochemical reactions were comparable to the findings of Efstratiou et al. (1994) and Sippel et al. (1995). However, in other studies, $\beta$-Dgalactosidase activity has been considered negative for human group C and G (Devriese et al., 1986;
Efstratiou et al., 1994) and for group L (Farrow \& Colllins, 1984) streptococci. In the present investigation, most of the strains were $\beta$-D-galactosidasepositive. Several authors have also found a high proportion of human group C, G (Slifkin \& Gil, 1983) and group L streptococci (Sippel et al., 1995) to be able to produce this enzyme. They also determined $\beta$-Dgalactosidase activity with 4-methylumbelliferyl-conjugated $\beta$-D-galactoside as substrate.

Our data are in agreement with the division of $S$. dysgalactiae into two subspecies, but differ from the findings of Vandamme et al. (1996) in that $\beta$-haemolytic group L and group C ('S. equisimilis') streptococci from animals were clustered together. The results of the present study also showed that the $\alpha$ haemolytic group $\mathrm{C}$ strains are distinct from the $\beta$ haemolytic group $\mathrm{C}, \mathrm{G}$ and L strains. Therefore, we propose that they are placed in a distinct subspecies, Streptococcus dysgalactiae subsp. dysgalactiae. On the other hand, the $\beta$-haemolytic strains should be allocated to another subspecies, $S$. dysgalactiae subsp. equisimilis. Although there may be host-adapted ecovars within this subspecies, in the present report differences in DNA-DNA reassociation experiments correlated more with physiological variation than with host origin (ecovariation). This was exemplified by group C strains, and, particularly, by group L strains. Human isolates of group L were not distinguishable from animal isolates. Furthermore, group L strains could be discriminated from the $S$. dysgalactiae subsp. dysgalactiae strains but not from subsp. equisimilis strains. Although there is no practical reason to subdivide a species on the basis of DNA-DNA reassociation experiments, the two distinct DNA-DNA clusters of strains also correlated with physiological characteristics that can be recommended for the differentiation of strains, including the haemolytic activity. According to our proposal, the subspecies dysgalactiae contains only $\alpha$-haemolytic strains and the subspecies equisimilis contains all $\beta$ haemolytic $S$. dysgalactiae strains. Haemolytic activity is one of the most stable and classical phenotypic characteristics used to differentiate the streptococci and can be easily performed in diagnostic laboratories.

Phenotypic characteristics are also helpful in differentiating some of the ecovars. The group $\mathrm{C}$ ' $S$. equisimilis' strains with the animal biotype can be distinguished from those with human biotype by biochemical tests. Strains of groups C and G streptococci isolated from humans appear to be very similar. Their homology is also suggested by similarities in some surface structures that are known to contribute to the virulence of the organism. Streptococcal IgGbinding proteins ( $\mathrm{Fc}$ receptors) have been described for $S$. dysgalactiae. The type III Fc receptors from groups $\mathrm{C}$ and $\mathrm{G}$ streptococci (Bjorck \& Kronvall, 1984; Sjorbring et al., 1991) have been shown to be similar. Jonsson et al. (1994) and Jonsson \& Muller (1994) have recently cloned and sequenced two genes from $S$. dysgalactiae encoding Fc receptors with a new 
molecular architecture. These proteins, called protein MIG and protein MAG, represent new variants of streptococcal IgG-binding proteins. Group L Streptococcus strains have $\mathrm{Fc}$ receptors, but information about their structure is scarce (Sippel \& Lämmler, 1995). In addition, M-like proteins have been demonstrated in groups C, G (Jones \& Fischetti, 1987) and L (Sippel et al., 1995) but their occurrence in $\alpha$-haemolytic streptococci is unknown. The structural variations of $\mathrm{Fc}$ receptors and the presence of M-like proteins are consistent with our results and subspecies proposal.

Confusion regarding which strains to be included in $S$. dysgalactiae subsp. equisimilis strains is present in the literature. Bergey's Manual of Determinative Bacteriology (Holt et al., 1994) places the human group C streptococci in $S$. equi subsp. equisimilis. This nomenclature has also been adopted in a recent study (Turner et al., 1997). The allocation of the human group $\mathrm{C}$ and $\mathrm{G}$ streptococci to the same subspecies will have epidemiological and clinical implications. In fact, most studies include only strains that exhibit group C or $\mathrm{G}$ antigen. Consequently, the frequency of $S$. dysgalactiae subsp. equisimilis as a cause of infections is undervalued.

\section{Emendation of the description of Streptococcus dysgalactiae subsp. dysgalactiae}

The characteristics of $S$. dysgalactiae subsp. dysgalactiae are the same as those described by Farrow \& Collins (1984), with the following exceptions. The strains are $\alpha$-haemolytic and nonhaemolytic and react with Lancefield group C antigen. Streptokinase activity on human plasminogen does not occur (Vandamme et al., 1996). Additional biochemical characteristics are shown in Table 2. These strains belong to DNA relatedness sub-group 1. This subspecies is commonly found associated with bovine mastitis and may also be isolated from bovine vagina.

\section{Emendation of the description of Streptococcus dysgalactiae subsp. equisimilis}

The characteristics of $S$. dysgalactiae subsp. equisimilis are the same as those described by Farrow \& Collins (1984), with the following exceptions. All strains are $\beta$ haemolytic and may possess Lancefield group $\mathrm{C}, \mathrm{G}$ or $\mathrm{L}$ antigen. Streptokinase activity occurs on human plasminogen (Vandamme et al., 1996). Additional biochemical characteristics are shown in Table 2. There are several phenotypic categories within this subspecies which have been found in isolates from different animal ecovars. These ecovars are found in the normal human throat, vagina and skin and in other animal sites. They are also found in miscellaneous infections of humans and domestic animals. All the phenotypic categories belonging to this subspecies are included in DNA relatedness sub-group 2.

\section{ACKNOWLEDGEMENTS}

This study was supported in part by Conselho Nacional de Desenvolvimento Científico e Tecnológico (CNPq), Coordenação de Aperfeiçoamneto de Pessoal de Nivel Superior (CAPES), Financiadora de Estudos e Projetos (FINEP), Fundação de Amparo à Pesquisa do Estado do Rio de Janeiro (FAPERJ) and Ministério da Ciência e Tecnologia (MCT/PRONEX), Brazil. We thank Carlos Ausberto B. de Souza, Marilene Ramos da Silva and Paulo César Maia of the Instituto de Microbiologia, Universidade Federal do Rio de Janeiro, Brazil for technical assistance. We also thank Dr Raquel S. Pacheco for continuous support and Elisa Cupolillo for helpful suggestions.

\section{REFERENCES}

Balmelli, T. \& Piffaretti, J. (1996). Analysis of the genetic polymorphism of Borrelia burgdorferi sensu latu by multilocus enzyme electrophoresis. Int J Syst Bacteriol 46, 167-172.

Beebe, J. L. \& Koneman, E. W. (1995). Recovery of uncommon bacteria from blood: association with neoplastic disease. Clin Microbiol Rev 8, 336-356.

Bert, F., Picard, B., Lambert-Zechovsky, N. \& Goullet, P. (1995). Identification and typing of pyogenic streptococci by enzyme electrophoretic polymorphism. J Med Microbiol 42, 442-451.

Bjorck, L. \& Kronvall, G. (1984). Purification and some properties of streptococcal protein $\mathbf{G}$, a novel IgG-binding reagent. $J$ Immunol 133, 969-973.

Brenner, D. J., McWhoter, A. C., Leete Knutson, J. K. \& Steigerwalt, A. G. (1982). Escherichia vulneris: a new species of Enterobacteriaceae associated with human wounds. $J$ Clin Microbiol 15, 1133-1140.

Bucher, A. \& Gaustad, P. (1990). Septicemia and endocarditis caused by group $\mathrm{G}$ streptococci in a Norwegian hospital. Eur $J$ Microbiol Infect Dis 9, 251-256.

Carmeli, Y., Schapiro, J. M., Neeman, D., Yinnon, A. M. \& Alkan, M. (1995). Streptococci group C bacteremia. Arch Intern Med 155, 1170-1176.

Cimolai, N. \& Mah, D. (1991). $\beta$-D-Glucuronidase activity assay for rapid differentiation of species within $\beta$-haemolytic groups C and G streptococci. J Clin Pathol 44, 824-825.

Cimolai, N., Morrison, B. J., MacCulloch, L., Smith, D. F. \& Hlady, J. (1991). $\beta$-Haemolytic non group $A$ streptococci and pharyngitis: a case control study. Eur J Pediatr 150, 776-779.

Cupolillo, E., Grimaldi, G., Jr \& Momen, H. (1994). A general classification of New World Leishmania using numerical zymotaxonomy. Am J Trop. Med Hyg 50, 296-311.

Devriese, L. A., Hommez, J., Kilpper-Bälz, R. \& Schleifer, K.-H. (1986). Streptococcus canis sp. nov.: a species of group G streptococci from animals. Int $J$ Syst Bacteriol 36, 422-425.

Efstratiou, A., Colman, G., Hahn, G., Timoney, J. F., Boeufgras, J. M. \& Monget, D. (1994). Biochemical differences among human and animal streptococci of Lancefield group $\mathrm{C}$ or group $\mathrm{G}$. $J$ Med Microbiol 41, 145-148.

Ezaki, T., Facklam, R., Takeuchi, N. \& Yabuuchi, E. (1986). Genetic relatedness between the type strain of Streptococcus anginosus and minute-colony-forming beta-hemolytic streptococci carrying different Lancefield grouping antigens. Int J Syst Bacteriol 36, 345-347. 
Facklam, R. R. \& Washington, J. A., II (1991). Streptococcus and related catalase-negative gram-positive cocci. In Manual of Clinical Microbiology, pp. 238-257. Edited by A. Balows, W. J. Hausler, Jr. K. L. Hermann, H. D. Isermberg \& H. J. Shadomy, Washington, DC: American Society for Microbiology.

Farrow, J. A. E. \& Collins, M. D. (1984). Taxonomic studies on streptococci of serological groups $\mathrm{C}, \mathrm{G}$ and $\mathrm{L}$ and possibly related taxi. Syst Appl Microbiol 5, 438-493.

Garvie, E. I., Farrow, J. A. E. \& Bramley, A. J. (1983). Streptococcus dysgalactiae (Diernhofer) nom. rev. Int J Syst Bacteriol 33, $404-405$.

Harris, H. \& Hopkinson, D. A. (1976). The enzymes. In Handbook of Enzyme Electrophoresis in Human Genetics, chapter 4. New York: Neu York Science Publishers.

Holt, J. G., Krieg, N. R., Sneath, P. H. A., Stanley, J. T. \& Willians, S. T. (1994). Gram-positive cocci. In Bergey's Manual of Determinative Bacteriology, 9th edn, pp. 527-558. Baltimore: Williams \& Wilkins.

Jones, K. F. \& Fischetti, V. A. (1987). Biological and immunochemical identity of $M$ protein on group $G$ streptococci with $M$ protein on group A streptococci. Infect Immun 55, 502-506.

Jonsson, H. \& Muller, H. P. (1994). The type III Fc receptor from Streptococcus dysgalactiae is also an $\alpha 2$-macroglobulin receptor. Eur J Biochem 220, 819-826.

Jonsson, H., Frykberg, E. R., Rantamaki, L. \& Guss, B. (1994). MAG, a novel plasma protein receptor from Streptococcus dysgalactiat. Gene 143, 85-89.

Kilpper-Bälz, R. \& Schleifer, K.-H. (1984). Nucleic acid hybridization and cell wall composition studies of pyogenic streptococci. FEMS Microbiol Lett 24, 355-356.

Lancefield, R. C. (1933). A serological differentiation of human and other groups of hemolytic streptococci. J Exp Med 57, $571-595$

Lancefield, R. C. \& Hare, R. (1935). The serological differentiation of pathogenic and non-pathogenic strains of hemolytic streptococci from parturient women. $J$ Exp Med 61, 335-349.

Lawrence, J., Yajko, D. M. \& Hadley, W. K. (1985). Incidence and characterization of $\beta$-hemolytic Streptococcus milleri and differentiation form $S$. pyogenes (group A), $S$. equisimilis (group C) and large-colony group $\mathrm{G}$ streptococci. J Clin Microbiol 22, $772-777$

Momen, H. \& Salles, C. A. (1985). Enzyme markers for Vibrio cholerae identification of classical, El Tor and environmental strains. Trans R Soc Trop Med Hyg 79, 773-776.

Musser, J. M., Hewlett, E. S., Peppler, M. S. \& Selander, R. K. (1986). Genetic diversity and relationships in populations of Bordetella spp. J Bacteriol 166, 230-237.

Pasteur, N., Pasteur, G., Bonhomme, F., Catala, J. \& BrittonDavidian, J. (1988). Laboratory techniques. In Practical Isozyme Genetics, pp. 83-150. Chichester: Ellis Horwood.
Selander, R. K., Caugant, D. A., Ochaman, H., Musser, J. M., Gilmour, M. N. \& Whittan, T. S. (1986). Methods of multilocus enzyme electrophoresis for bacterial population genetics and systematics. Appl Environ Microbiol 51, 873-884.

Sippel, K. \& Lämmler, C. (1995). Further studies on immunoglobulin $\mathrm{G}$ and albumin-binding properties of streptococci of serological group L. J Vet Med B 42, 421-426.

Sippel, K., Dulffer-Schneitzer, B. \& Lämmler, C. (1995). Characteristics properties of streptococci of serological group L. $J \mathrm{Vet}$ Med B 42, 42-50.

Sjorbring, U., Bjorck, L. \& Kastern, W. (1991). Streptococcal protein $\mathrm{G}$ : gene structure and binding properties. $J$ Biol Chem 266, 399-405.

Slifkin, M. \& Gil, G. M. (1983). Rapid chemical tests for the identification of groups A, B, C, F and G streptococci from throat cultures. J Clin Microbiol 18, 29-32.

Sneath, P. H. A. \& Sokal, R. R. (1973). Numerical Taxonomy, pp. 131-133. San Francisco: Freeman.

Stackebrandt, E. \& Goebel, B. M. (1994). Taxonomic note: a place for DNA-DNA reassociation and 16S rRNA sequence analysis in the present species definition in bacteriology. Int $J$ Syst Bacteriol 44, 846-849.

Teixeira, L. M., Facklam, R. R., Steigerwalt, A. G., Pigott, N. E., Merquior, V. L. \& Brenner, D. J. (1994). Correlation between phenotypic characteristics and DNA relatedness within Enterococcus faecium strains. J Clin Microbiol 33, 1520-1523.

Turner, J. C., Hayden, F. G., Lobo, M. C., Ramirez, C. E. \& Murren, D. (1997). Epidemiology evidence for Lancefield group C betahemolytic streptococci as a cause of exudative pharyngitis in college students. J Clin Microbiol 35, 1-4.

Vandamme, P., Pot, B., Falsen, E., Kersters, K. \& Devriese, L. A. (1996). Taxonomic study of Lancefield streptococcal groups C, $\mathrm{G}$, and L (Streptococcus dysgalactiae) and proposal of $S$. dysgalactiae subsp. equisimilis subsp. nov. Int $J$ Syst Bacteriol 46, 774-781.

Vieira, V. V. \& Castro, A. C. D. (1994). Biochemical properties and whole-cell protein profiles of group $\mathrm{G}$ streptococci isolated from dogs. J Appl Bacteriol 77, 408-411.

Wayne, L. G., Brenner, D. J., Colwell, R. R. \& 9 other authors (1987). International Committee on Systematic Bacteriology. Report of the ad hoc committee on reconciliation of approaches to bacterial systematics. Int J Syst Bacteriol 37, 463-464.

Whiley, R. A., Fraser, H., Hardie, J. M. \& Beighton, D. (1990). Phenotypical differentiation of Streptococcus intermedius, Streptococcus constellatus and Streptococcus anginosus strains within the 'Streptococcus milleri group'. J Clin Microbiol 28, 1497-1501.

Zahner, V., Momen, H., Salles, C. A. \& Rabinovitch, L. (1989). A comparative study of enzyme variation in Bacillus cereus and Bacillus thuringiensis. J Appl Bacteriol 67, 275-282. 
